\title{
Sex Differences in Longevity and in Responses to Anti-Aging Interventions: A Mini-Review
}

\author{
Steven N. Austad ${ }^{\mathrm{a}}$ Andrzej Bartke ${ }^{\mathrm{b}}$ \\ ${ }^{a}$ Department of Biology, The University of Alabama at Birmingham, Birmingham, Ala., and \\ ${ }^{b}$ Department of Medicine, Southern Illinois University School of Medicine, Springfield, III., USA
}

\section{Key Words}

Sexual dimorphism · Insulin-like growth factor · Life expectancy $\cdot$ Sex differences $\cdot$ Anti-aging $\cdot$ Female longevity bias $\cdot$ Mechanistic target of rapamycin

\begin{abstract}
A robust, often underappreciated, feature of human biology is that women live longer than men not just in technologically advanced, low-mortality countries such as those in Europe or North America, but across low- and high-mortality countries of the modern world as well as through history. Women's survival advantage is not due to protection from one or a few diseases. Women die at lower rates than men from virtually all the top causes of death with the notable exception of Alzheimer's disease, to which women are particularly prone. Yet, despite this robust survival advantage, women across countries of the world suffer worse health throughout life. The biological mechanisms underlying either longer female survival or poorer female health remain elusive and understudied. Mechanisms of mammalian biology, particularly with respect to aging and disease, are most easily studied in laboratory mice. Although there are no consistent differences in longevity between mouse sexes even within single genotypes, there are often substantial differ-
\end{abstract}

ences in individual studies, sometimes favoring females, other times males. Investigating the environmental causes of this puzzling variation in longevity differences could prove illuminating. Sex differences in response to life-extending genetic or pharmacological interventions appear surprisingly often in mice. Longevity enhancement due to reduced signaling through IGF-1 or mTOR signaling typically favors females, whereas enhancement via a range of pharmacological treatments favors males. These patterns could be due to interactions of the interventions with sex steroids, with adiponectin or leptin levels, or with the sex differences in immune function or the regional distribution of body fat. Clearly, generalizations from one sex cannot be extended to the other, and inclusion of both sexes in biomedical studies of human or other animals is worth the effort and expense.

(c) 2015 S. Karger AG, Basel

\section{Introduction}

Recent biomedical and demographic research has provided numerous examples of major sex differences in physiological characteristics unrelated to reproduction and in responses to genetic, nutritional, or pharmacological interventions. The renewed appreciation of the mag-

\section{KARGER}

E-Mail karger@karger.com www.karger.com/ger
Steven N. Austad, PhD

Department of Biology, The University of Alabama at Birmingham 1720 Second Avenue South, CH 464 Birmingham, AL 35294-1170 (USA)

E-Mail austad@uab.edu 


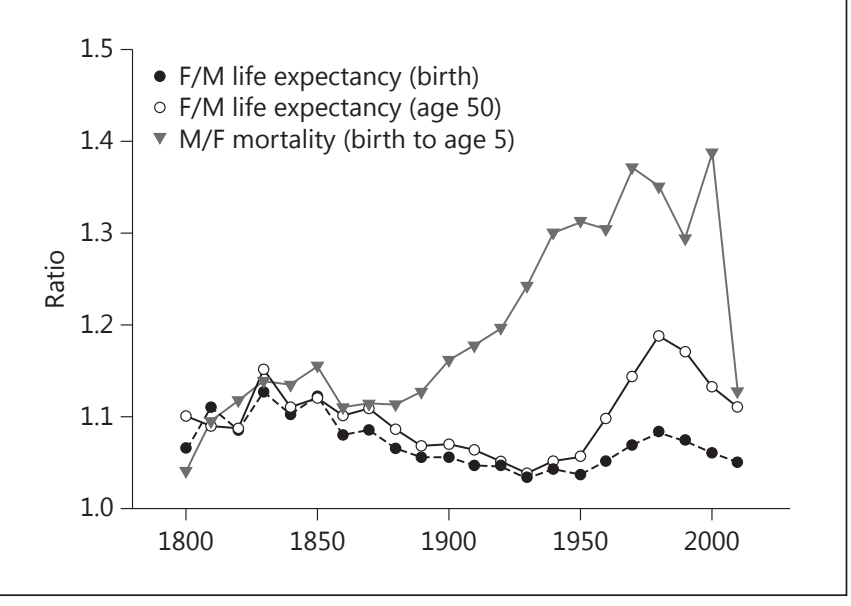

Fig. 1. Female survival advantage (Sweden from 1800 to 2010). Note that the sex ratio of all three metrics is always greater than 1 , indicating better female survival. $\mathrm{F}=$ Female; $\mathrm{M}=$ male. Source: Human Mortality Database (www.mortality.org; accessed October $30,2014)$.

nitude and importance of the impact of sexual dimorphism on the results of both 'basic' and clinical studies leads to novel and, in some cases, unexpected insights.

It is in this context that this article briefly reviews the evidence that life expectancy and patterns of age-related disease exhibit great and amazingly consistent differences between women and men, that the impact of sex on longevity of common laboratory mammals is very different, and that responses to life-extending ('anti-aging') interventions can be very different in females than in males.

Women live longer than men at all times and everywhere. An examination of The Human Mortality Database (www.mortality.org), which provides detailed historical population demographic records from 37 countries with particularly reliable data, reveals that women experienced greater life expectancy at birth than men in every one of those countries for every year on record. An extensive and enlightening example is Sweden, which has more complete and reliable demographic records than any other country. Since 1800, when life expectancy at birth was 33 years for women and 31 years for men, to today when it is 83.5 years for women and 79.5 years for men, women lived longer than men in every single year (fig. 1). In fact, as figure 1 also shows, from the age of 50 years, women also lived longer than men in every year. So this consistent life expectancy difference is not due to early deaths such as those due to war or infant diseases. In fact, even as infants, females survive better than males.
Male mortality in Sweden from birth to the age of 5 years was greater than female mortality in 1800 , when one third of babies died by their 5th birthday, and it is still true today, when far less than $1 \%$ of babies die between birth and the age of 5 years. This remarkably consistent survival advantage of women compared with men in early life, in late life, and in total life is not confined to Sweden but is seen in every country in every year for which reliable birth and death records exist. There may be no more robust pattern in human biology.

A variety of cultural, environmental, and socioeconomic factors will affect the magnitude of sex differences in life expectancy though. Among modern, industrialized countries, the gender gap in life expectancy ranges from about 4 years (e.g. Israel and the Netherlands) to more than 10 years in the countries of the former Soviet Union. Men not only consistently have higher mortality rates than women, they also have consistently greater variation in mortality than women among subpopulations [1]. That is, some subpopulations of men are considerably worse off than similar subpopulations of women, which would have the effect of increasing the size of the gender gap in life expectancy. To the extent that subpopulation differences are reduced, the gap will narrow. A good example of this is shown in an analysis of life expectancy among the 3,143 counties in the USA, which finds an 18year difference in life expectancy between men in the longest-lived and those in the shortest-lived counties compared with only a 13-year difference for women [2]. Similarly, the education (or its lack) has a greater impact on male than on female life expectancy [3].

As should not be surprising given the robustness of this pattern, women die at lower age-adjusted rates than men from a broad range of diseases. For instance, in the USA, in 2010 women died at lower rates than men of 12 of the top 15 causes of death [4]. Two causes (stroke and Parkinson's disease) were approximately equal between the sexes. Women died at higher rates than men only of Alzheimer's disease.

Several hypotheses have been put forward to explain the gender gap in life expectancy. For instance, by several measures women have a more responsive immune system than men $[5,6]$. As inflammation is now implicated in many diseases, differences in inflammatory responsiveness could conceivably play a role in the gender gap. Another possibility is that sex hormones may be involved, either men's reproductive hormones increasing susceptibility to a host of diseases or women's hormones providing resistance to diseases. Some evidence - not the strongest evidence, however - supports the hypothesis of the 
life-shortening impact of men's hormones. Specifically, longevity records from 81 Korean eunuchs who lived at the royal court in the 16th to 19th centuries found that eunuchs lived 15-20 years longer than contemporary intact controls [7]. The size of this difference is nearly the same as 20th-century records recovered from an American institution for the mentally retarded, in which castration of both men and women was performed, mainly for behavioral reasons [8]. Comparison of 297 castrated men with 735 intact men from the same institution revealed that on average the castrated men lived 13.6 years longer than the intact men. Moreover, the earlier in life men were castrated, the longer they lived. For women, the prediction from the sex hormone hypothesis would be that removal of ovaries should reduce longevity. However, a comparison of 23 oophorectomized with 309 intact women did not uncover any significant difference in longevity. Another prediction from the same hypothesis suggests that postmenopausal women receiving hormone replacement should outlive women eschewing hormone replacement. No evidence for such an effect exists. In fact, existing evidence suggests that the opposite might be true [9].

Examination of sex differences in health paints a somewhat different picture than sex differences in survival though. Across countries, including both low- and highincome countries, women display higher overall rates of physical illness than men at all adult ages. They experience more disabilities and activity limitations. For instance, women in high-income countries are more likely than men to report difficulties in walking, climbing stairs, dressing, and other common activities. In low-income countries, women report greater difficulties than men in a wide range of common activities such as bending over, pumping water, or walking a specified distance. In addition, women make more doctor visits, spend more days hospitalized, and take more medications than do men [10-12]. Even in Russia, which has one of the largest sex differences in life expectancy in the world, with a male disadvantage of more than 10 years, males report better health and physical functioning at ages of 55 years and higher [13].

Several hypotheses have been proposed to attempt to explain this health-survival paradox. One hypothesis could be called the differential selection hypothesis. It posits that men are more likely than women to die of similarly serious diseases; therefore, surviving men will be healthier than surviving women. Unfortunately, there is scant evidence to support this hypothesis. A more plausible hypothesis is that women are more sensitive to physical discomfort and are more likely to seek medical atten- tion when it occurs. However, empirical support for explanations of this type is scant and uneven [11]. Moreover, this paradox is not seen only in wealthy, industrialized countries, where cultural norms might make such explanations most plausible. It is also found in places such as Jamaica, Malaysia, and Bangladesh, where access to medical care and treatment is particularly difficult for either gender $[14,15]$. At least part of the health-survival paradox can be uncontroversially attributed to the higher prevalence and severity of arthritis and musculoskeletal disease among older women. To what this higher prevalence and severity itself can be attributed is not obvious, however.

How general is the female longevity bias among other animal species? Is it an idiosyncrasy of human biology or a general pattern within mammals? This question proves surprisingly difficult to answer. A key consideration is whether one focuses on wild or captive populations. Patterns of sexual differences in aging and longevity evolved, of course, under conditions in nature. On the other hand, mortality patterns in wild populations are dominated by extrinsic causes such as climatic events, competitive interactions within and between species, parasites, infectious diseases, and predation, all of which can mask intrinsic physiological differences. Given this caveat, in nature, females of socially polygynous species such as African lions or red deer - which include a large majority of mammals - often live longer than males. By contrast, survival is approximately equivalent or males live somewhat longer in socially monogamous species, such as most birds and a few mammals such as African wild dogs [16].

Among higher primates (monkeys and apes), females are generally longer-lived than males in wild populations [17]. In captive populations, however, the picture is more complex. In some monkey species, particularly those in which males contribute significantly to parental care, captive males live longer than captive females [18]. In other species - such as baboons, which have extensive captive demographic records - there appears to be no sex difference in longevity [19]. These various patterns among species suggest that the heterogametic sex hypothesis is unlikely to be valid. There is no single difference in life expectancy that applies to all mammals.

Importantly though, in apes (chimpanzees, gorillas, orangutans, and gibbons), our closest evolutionary relatives, females appear to uniformly live longer than males both in the wild and in captivity $[18,20]$. Thus, humans appear to have inherited from our ape-like ancestors our propensity for women to outlive men. The mechanism(s) underlying this sex difference remain speculative though.
Austad/Bartke 
Table 1. Some studies showing major sex differences in response to life-extending interventions

\begin{tabular}{llll}
\hline Genotype/treatment & $\begin{array}{l}\text { Male } \\
\text { increase }\end{array}$ & $\begin{array}{l}\text { Female } \\
\text { increase }\end{array}$ & Reference \\
\hline IGF-1R heterozygote & 0 & ++ & Holzenberger et al. [30], 2003 \\
IGF-1R heterozygote & 0 & + & Bokov et al. [31], 2011 \\
IR heterozygote & + & 0 & Nelson et al. [48], 2012 \\
IRS1 knockout & 0 & ++ & Selman et al. [32], 2008 \\
RIIb (PKA) KO & ++ & 0 & Enns et al. [49], 2009 \\
Overexpress Sirt6 & ++ & 0 & Kanfi et al. [50], 2012 \\
S6K1 knockout & 0 & ++ & Selman et al. [34], 2009 \\
mtor ${ }^{+-}$; mlst8 ${ }^{+/}$ & 0 & + & Lamming et al. [44], 2012 \\
NDGA & + & 0 & Strong et al. [38], 2008 \\
Aspirin & + & 0 & Strong et al. [38], 2008 \\
Acarbose & ++ & + & Harrison et al. [39], 2014 \\
17- $\alpha$-Estradiol & + & 0 & Harrison et al. [39], 2014 \\
\hline
\end{tabular}

$0=$ No change $;+=$ small, significant change $;++=$ large, significant change.

\section{Sex Differences in Longevity in Mice}

Among mammals, mechanistic studies are most easily done in laboratory mice. Could mice be informative as to sex differences in longevity? The literature on aging is beset with confusion as to the existence or nature of sex differences in survival in mice [21]. One can find claims that males are the longer-lived sex [22], that there is no sex difference [23], and that females live longer [24]. It turns out that all of these authors are correct. That is, sex differences in mouse longevity vary greatly. Austad [21] summarized 118 mouse survival studies that reported either mean or maximum longevity in both sexes. Results of any dietary or genetic treatments were ignored and only the 'control' longevities considered. In 65 (55\%) of the studies, male longevity exceeded that of females, but 51 (43\%) of the studies found the reverse. The majority of these longevity differences tended to be small. However, about $10 \%$ of the studies reported differences of $20 \%$ or more, and these studies were about equally divided between greater male versus greater female longevity.

One obvious explanation for this variation is the mouse genotype. All inbred laboratory mouse strains have their idiosyncrasies. However, 29 different studies of the single $\mathrm{C} 57 \mathrm{BL} / 6$ strain found almost as great a variation in longevity differences between the sexes as for the entire 118-study data set [21]. Longevity differences in both directions also were reported in $\mathrm{DBA} / 2$ and $\mathrm{BALB} / \mathrm{c}$ mice, among $\mathrm{F} 1$ genotypes, in mixed genotypes, and even among wild-derived mouse stocks. Clearly, subtle differ-

Exploring Factors of Sex-Based Longevity ences between laboratory environments or husbandry practices can have a substantial impact on sex-specific survival. If we could identify the source or sources of this variation, it could potentially teach us a lot about sex differences in aging.

\section{Sex Differences in Life-Extending Interventions in Mice}

Life-extending interventions are multiplying rapidly in mice, and a surprising number of these impact only one sex or impact one sex considerably more than the other (table 1). Calorie restriction, transgenic overexpression of the 'hunger hormone' fibroblast growth factor 21 (FGF21), targeted deletion ('knockout') of growth hormonereleasing hormone $(\mathrm{GHRH})$ or growth hormone $(\mathrm{GH})$ receptors, and hereditary deficiency of $\mathrm{GH}$, prolactin, and thyrotropin extend longevity in both female and male mice [25-29]. A thorough review of all published mouse and rat calorie restriction studies which distinguished the results by sex found median longevity to be extended by $12 \%$ on average in male mice, by $16 \%$ in female mice, by $31 \%$ in male rats, and by $26 \%$ in female rats [25]. However, reduction in the levels of the key mediator of $\mathrm{GH}$ actions, insulin-like growth factor 1 (IGF-1) [30, 31], or deletion of various genes acting 'downstream' from $\mathrm{GH}$ and IGF-1 receptors extends longevity in females only or has a markedly greater effect on lifespan in females than in males. This includes mice with deletion of insulin receptor substrate (IRS1) [32], brain-specific deletion of IRS2 [33], or deletion of S6 kinase 1 [34], an important target of the mechanistic target of rapamycin (mTOR).

A particularly interesting example of sex-specific effects of genetically manipulating endocrine signaling on longevity is provided by mice heterozygous for the deletion of the IGF-1 receptor. In 2003, the Holzenberger laboratory reported a major (approx. 33\%) extension of lifespan in $I g f 1 r^{+/-}$females, with a similar but smaller and statistically nonsignificant trend in males [30]. Eight years later, a paper from the Richardson laboratory reported that heterozygous deletion of the same gene in a different strain of mice (C57BL/6 rather than 129/SvPas) resulted in a significant but much smaller (approx. 5\%) extension of longevity in females and a trend for reduced longevity in males [31]. Earlier this year, Xu et al. [35] from the Holzenberger group confirmed that C57BL/6 IGF-1R ${ }^{+/-}$females live longer than controls, while males exhibit a reduction in maximal lifespan. Importantly, these investigators related differences between lifespan extension they 
produced in C57BL/6 and 129/SvPas mice (11 vs. $33 \%$ ) to quantitative differences between these two strains in IGF1 signaling and in the response of this signaling pathway to heterozygosity for IGF1R deletion.

We are not aware of any studies aimed specifically at explaining sex differences in the impact of genetic suppression of the IGF-1, insulin, or mTOR pathways on aging and longevity or identifying mechanisms that could be involved. There is evidence that estradiol, the principal female sex hormone, reduces hepatic sensitivity to $\mathrm{GH}$, while male sex hormones synergize with the growth-promoting effects of the somatotropic axis (GH and IGF-1) $[36,37]$. Studies involving gonadectomy and sex hormone replacement would be necessary to determine whether these sex hormone actions are in any way related to differential responses of females and males to genetic manipulation of the somatotropic axis or its targets.

The tendency of mutations interfering with IGF-1 or mTOR signaling to produce an extension of longevity exclusively or preferentially in females contrasts with effects of several pharmacological anti-aging interventions. Testing a variety of drugs for their impact on mouse longevity identified several compounds that - at least at the doses used - either extend longevity only in males or have a more pronounced 'anti-aging' effect in males than in females. These drugs include: aspirin; another anti-inflammatory compound, nordihydroguaiaretic acid (NDGA); acarbose, and 17- $\alpha$-estradiol, a compound with no or very little sex hormone activity $[38,39]$. The mechanisms linking the action of these compounds to aging remain to be fully clarified. In fact, sex differences in the effects of pharmacological treatments differ in a fundamental way from sex differences in genetic knockouts, in that they may be due to differential bioavailability of the drug in question due to sex differences in metabolism or clearance. That appears to be the case, for instance, for aspirin and NDGA [38]. By contrast, a gene that is knocked out in one sex is necessarily knocked out in the other as well.

Mechanisms linking the action of the above compounds to aging are unlikely to include altered activity of the somatotropic axis but may involve some functions modulated by $\mathrm{GH}$, e.g. inflammation and insulin signaling. The reasons for the exclusive or enhanced anti-aging activity of these compounds in males are unknown, but the well-documented sexual dimorphism in the activity of hepatic drug-metabolizing enzymes [40,41] offers one theoretical possibility. Intriguingly, sex dimorphism in the activity of these enzymes reflects differences between the patterns of pulsatile GH release in males versus females $[41,42]$.
However, greater effects on male longevity are not a consistent feature of pharmacological anti-aging interventions. The inhibitor of mTOR signaling rapamycin extends longevity in both sexes of mice, but its effect is greater in females [43]. The ability of rapamycin to inhibit mTOR complex 2 and the detrimental impact of RICTOR depletion on male survival may account for this difference [44].

In the context of sex differences in response to a variety of genetic and pharmacological interventions, it is of considerable interest that the sexual dimorphism in the hepatic expression of numerous genes, including those involved in metabolism of steroid hormones and xenobiotics, is virtually eliminated in $\mathrm{GH}$-deficient, long-lived Ames dwarf mice [45]. Similar findings were obtained in 'little' (Ghrhrit) and in $\mathrm{Ghr}^{-/-}$mice, which, unlike the Ames dwarfs, have an isolated deficiency of GH signaling [46].

Countless physiological differences between females and males of the same species could contribute to the differences in longevity and in responses to anti-aging interventions discussed in this article. In addition to different levels and ratios of androgenic and estrogenic steroids, sex differences in the levels of adiponectin and leptin, in the distribution of adipose tissue (and the associated differences in its secretory activity), and in the function of the immune system represent some of the obvious 'candidate mechanisms' that remain to be explored in this context.

\section{Conclusions}

There are two important conclusions that emerge from the available data. First, women have a robust survival advantage over men, whereas men have a robust health advantage over women. This intriguing paradox deserves more investigation. It would be a major boon to human health if men lived as long as women and if women maintained their health as well as men. Second, because sex differences are broad and unpredictable, inclusion of both sexes in all biomedical studies - regardless of species - is well worth the effort and expense involved. In the USA, since the early 1990s both sexes have been routinely included in National Institutes of Health (NIH)funded clinical studies. However, similar attention has not been paid to the sex balance in animal studies. These have traditionally been heavily male biased. In May 2014, the NIH issued a policy statement promising to redress this imbalance [47]. We strongly support this effort.
Austad/Bartke 


\section{References}

1 Luy M, Gast K: Do women live longer or do men die earlier? Reflections on the causes of sex differences in life expectancy. Gerontology 2014;60:143-153.

2 Wang H, Schumacher AE, Levitz CE, Mokdad AH, Murray CJ: Left behind: widening disparities for males and females in US county life expectancy, 1985-2010. Popul Health Metr 2013;11:8

3 Olshansky SJ, Antonucci T, Berkman L, Binstock RH, Boersch-Supan A, Cacioppo JT, Carnes BA, Carstensen LL, Fried LP, Goldman DP, Jackson J, Kohli M, Rother J, Zheng Y, Rowe J: Differences in life expectancy due to race and educational differences are widening, and many may not catch up. Health Aff (Millwood) 2012;31:1803-1813.

4 Murphy SL, Xu J, Kochanek KD: Deaths: final data for 2010. Natl Vital Stat Rep 2013;61:1117.

5 Oertelt-Prigione S: The influence of sex and gender on the immune response. Autoimmunity Rev 2012;11:A479-A485.

6 Ferguson JF, Patel PN, Shah RY, Mulvey CK, Gadi R, Nijjar PS, Usman HM, Mehta NN, Shah R, Master SR, Propert KJ, Reilly MP: Race and gender variation in response to evoked inflammation. J Transl Med 2013;11: 63.

7 Min KJ, Lee CK, Park HN: The lifespan of Korean eunuchs. Curr Biol 2012;22:R792-R793.

8 Hamilton JB, Mestler GE: Mortality and survival: comparison of eunuchs with intact men in a mentally retarded population. J Gerontol 1969;24:395-411.

9 Michels KB, Manson JE: Postmenopausal hormone therapy: a reversal of fortune. Circulation 2003; 107:1830-1833.

10 Verbrugge LM, Wingard DL: Sex differentials in health and mortality. Women Health 1987; 12;103-145.

11 Macintyre S, Ford G, Hunt K: Do women 'over-report' morbidity? Men's and women's responses to structured prompting on a standard question on long standing illness. Soc Sci Med 1999;48:89-98.

12 Christensen K, Doblhammer G, Rau R, Vaupel JW: Ageing populations: the challenges ahead. Lancet 2009;374:1196-1208.

13 Oksuzyan A, Shkolnikova M, Vaupel JW, Christensen K, Shkolnikov VM: Sex differences in health and mortality in Moscow and Denmark. Eur J Epidemiol 2014;29:243-252.

14 Murtagh KN, Hubert HB: Gender differences in physical disability among an elderly cohort. Am J Public Health 2004;94:1406-1411.

15 Rahman O, Strauss J, Gertler P, Ashley D, Fox $\mathrm{K}$ : Gender differences in adult health: an international comparison. Gerontologist 1994; 34:463-469.

16 Clutton-Brock TH, Isvaran K: Sex differences in ageing in natural populations of vertebrates. Proc Biol Sci 2007;274:3097-3104.

17 Bronikowski AM, Altmann J, Brockman DK, Cords M, Fedigan LM, Pusey A, Stoinski T,
Morris WF, Strier KB, Alberts SC: Aging in the natural world: comparative data reveal similar mortality patterns across primates. Science 2011;331:1325-1328.

18 Allman J, Rosin A, Kumar R, Hasenstaub A: Parenting and survival in anthropoid primates: caretakers live longer. Proc Natl Acad Sci USA 1998;95:6866-6869.

19 Martin LJ, Mahaney MC, Bronikowski AM, Dee CK, Dyke B, Comuzzie AG: Lifespan in captive baboons is heritable. Mech Ageing Dev 2002;123:1461-1467.

20 Littleton J: Fifty years of chimpanzee demography at Taronga Park Zoo. Am J Primatol 2005;67:281-298.

21 Austad SN: Sex differences in longevity and aging; in Masoro EJ, Austad SN (eds): Handbook of the Biology of Aging. San Diego, Academic Press, 2011, pp 479-496.

22 Ali SS, Xiong C, Lucero J, Behrens MM, Dugan LL, Quick KL: Gender differences in free radical homeostasis during aging: shorterlived female C57BL6 mice have increased oxidative stress. Aging Cell 2006;5:565-574.

23 Sanz A, Hiona A, Kujoth GC, Seo AY, Hofer T, Kouwenhoven E, Kalani R, Prolla TA, Barja G, Leeuwenburgh C: Evaluation of sex differences on mitochondrial bioenergetics and apoptosis in mice. Exp Gerontol 2007;42:173-182.

24 Viña J, Borras C, Gambini J, Sastre J, Pallardo FV: Why females live longer than males? Importance of the upregulation of longevityassociated genes by oestrogenic compounds. FEBS Lett 2005;579:2541-2545.

25 Swindell WR: Dietary restriction in rats and mice: a meta-analysis and review of the evidence for genotype-dependent effects on lifespan. Ageing Res Rev 2012;11:254-270.

26 Zhang Y, Xie Y, Berglund ED, Coate KC, He TT, Katafuchi T, Xiao G, Potthoff MJ, Wei W, Wan Y, Yu RT, Evans RM, Kliewer SA, Mangelsdorf DJ: The starvation hormone, fibroblast growth factor-21, extends lifespan in mice. Elife 2012;1:e0065.

27 Sun LY, Spong A, Swindell WR, Fang Y, Hill C, Huber JA, Boehm JD, Westbrook R, Salvatori R, Bartke A: Growth hormone-releasing hormone disruption extends lifespan and regulates response to caloric restriction in mice. Elife 2013;2:e01098.

28 Coschigano KT, Holland AN, Riders ME, List EO, Flyvbjerg A, Kopchick JJ: Deletion, but not antagonism, of the mouse growth hormone receptor results in severely decreased body weights, insulin, and insulin-like growth factor I levels and increased life span. Endocrinology 2003;144:3799-3810.

29 Brown-Borg HM, Borg KE, Meliska CJ, Bartke A: Dwarf mice and the ageing process. Nature 1996;384:33.

30 Holzenberger M, Dupont J, Ducos B, Leneuve P, Géloën A, Even PC, Cervera P, Le Bouc Y: IGF-1 receptor regulates lifespan and resistance to oxidative stress in mice. Nature 2003; 421:182-187.
31 Bokov AF, Garg N, Ikeno Y, Thakur S, Musi N, DeFronzo RA, Zhang N, Erickson RC, Gelfond J, Hubbard GB, Adamo ML, Richardson A: Does reduced IGF-1R signaling in Igf1 $r^{+/-}$mice alter aging? PLoS One 2011; 6:e26891.

32 Selman C, Lingard S, Choudhury AI, Batterham RL, Claret M, Clements M, Ramadani F, Okkenhaug K, Schuster E, Blanc E, Piper MD, Al-Qassab H, Speakman JR, Carmignac D, Robinson IC, Thornton JM, Gems D, Partridge L, Withers DJ: Evidence for lifespan extension and delayed age-related biomarkers in insulin receptor substrate 1 null mice. FASEB J 2008;22:807-818.

33 Taguchi A, Wartschow LM, White MF: Brain IRS2 signaling coordinates life span and nutrient homeostasis. Science 2007;317:369372 .

34 Selman C, Tullet JM, Wieser D, Irvine E, Lingard SJ, Choudhury AI, Claret M, Al-Qassab $\mathrm{H}$, Carmignac D, Ramadani F, Woods A, Robinson IC, Schuster E, Batterham RL, Kozma SC, Thomas G, Carling D, Okkenhaug K, Thornton JM, Partridge L, Gems D, Withers DJ: Ribosomal protein S6 kinase 1 signaling regulates mammalian life span. Science 2009; 326:140-144.

$35 \mathrm{Xu}$ J, Gontier G, Chaker Z, Lacube P, Dupont J, Holzenberger M: Longevity effect of IGF$1 \mathrm{R}^{+/-}$mutation depends on genetic background-specific receptor activation. Aging Cell 2014;13:19-28.

36 Leung KC, Johannsson G, Leong GM, Ho KK: Estrogen regulation of growth hormone action. Endocr Rev 2004;25:693-721.

37 Bondanelli M, Ambrosio MR, Margutti A, Franceschetti P, Zatelli MC, degli Uberti EC: Activation of the somatotropic axis by testosterone in adult men: evidence for a role of hypothalamic growth hormone-releasing hormone. Neuroendocrinology 2003;77:380387

38 Strong R, Miller RA, Astle CM, Floyd RA, Flurkey K, Hensley KL, Javors MA, Leeuwenburgh C, Nelson JF, Ongini E, Nadon NL, Warner HR, Harrison DE: Nordihydroguaiaretic acid and aspirin increase lifespan of genetically heterogeneous male mice. Aging Cell 2008;7:641-650.

39 Harrison DE, Strong R, Allison DB, Ames BN, Astle CM, Atamna H, Fernandez E, Flurkey K, Javors MA, Nadon NL, Nelson JF, Pletcher S, Simpkins JW, Smith D, Wilkinson JE, Miller RA: Acarbose, 17-a-estradiol, and nordihydroguaiaretic acid extend mouse lifespan preferentially in males. Aging Cell 2014;13: 273-282.

40 Shapiro BH, Agrawal AK, Pampori NA: Gender differences in drug metabolism regulated by growth hormone. Int J Biochem Cell Biol 1995;27:9-20.

41 Mode A, Gustafsson JA: Sex and the liver - a journey through five decades. Drug Metab Rev 2006;38:197-207. 
42 Waxman DJ, Pampori NA, Ram PA, Agrawal $\mathrm{AK}$, Shapiro BH: Interpulse interval in circulating growth hormone patterns regulates sexually dimorphic expression of hepatic cytochrome P450. Proc Natl Acad Sci USA 1991;88:6868-6872.

43 Miller RA, Harrison DE, Astle CM, Fernandez E, Flurkey K, Han M, Javors MA, Li X, Nadon NL, Nelson JF, Pletcher S, Salmon AB, Sharp ZD, Van Roekel S, Winkleman L, Strong R: Rapamycin-mediated lifespan increase in mice is dose and sex dependent and metabolically distinct from dietary restriction. Aging Cell 2014;13:468-477.
44 Lamming DW, Ye L, Katajisto P, Goncalves MD, Saitoh M, Stevens DM, Davis JG, Salmon $\mathrm{AB}$, Richardson A, Ahima RS, Guertin DA, Sabatini DM, Baur JA: Rapamycin-induced insulin resistance is mediated by mTORC2 loss and uncoupled from longevity. Science 2012;335:1638-1643.

45 Amador-Noguez D, Zimmerman J, Venable S, Darlington G: Gender-specific alterations in gene expression and loss of liver sexual dimorphism in the long-lived Ames dwarf mice. Biochem Biophys Res Commun 2005;332: 1086-1100.

46 Amador-Noguez D, Dean A, Huang W, Setchell K, Moore D, Darlington G: Alterations in xenobiotic metabolism in the longlived Little mice. Aging Cell 2007;6:453-470.

47 Clayton JA, Collins FS: Policy: NIH to balance sex in cell and animal studies. Nature 2014; 509:282-283.
48 Nelson JF, Strong R, Bokov A, Diaz V, Ward $\mathrm{W}$ : Probing the relationship between insulin sensitivity and longevity using genetically modified mice. J Gerontol A Biol Sci Med Sci 2012;67:1332-1338.

49 Enns LC, Morton JF, Treuting PR, Emond MJ, Wolf NS, Dai DF, McKnight GS, Rabinovitch PS, Ladiges WX: Disruption of protein kinase A in mice enhances health aging. PLoS One 2009;4:e5963.

50 Kanfi Y, Naiman S, Amir G, Peshti V, Zinman G, Nahum L, Bar-Joseph Z, Cohen HY: The sirtuin SIRT6 regulates lifespan in male mice. Nature 2012;483:218-221. 